\title{
CDK16 Gene
}

National Cancer Institute

\section{Source}

National Cancer Institute. CDK16 Gene. NCI Thesaurus. Code C24663.

This gene is involved in cell cycle regulation and signal transduction. 